\title{
ATRAVÉS DAS ONDAS DO RÁDIO: a mediação de um levante agrário em $1957^{1}$
}

\author{
Through the radio waves: the mediation of an agrarian revolt in 1957
}

\author{
Everly Pegoraro
}

Jornalista e professora do Departamento de Comunicação da Universidade Estadual do Centro-Oeste (Unicentro), Mestre em História Social pela Universidade Federal Fluminense. Guarapuava, PR-Brasil, e-mail: breverlyp@yahoo.com.br; everly@unicentro.br

\section{Resumo}

Em 1957, o sudoeste do Paraná atravessava um período conturbado, com a disputa de terras entre colonos, posseiros, companhias de terras e Estado. A situação atingiu seu clímax em outubro daquele ano, quando colonos e posseiros se organizaram em um levante armado conhecido como Revolta dos Posseiros de 1957, que aconteceu em vários municípios da região. Em Pato Branco, o inusitado desse conflito está na mediação feita pela Rádio Colmeia, que acabou por despertar a liderança política de Ivo Thomazoni, radialista e um dos líderes da revolta. Neste artigo, a partir dos depoimentos orais, constroem-se algumas das características da emissora. O objetivo é demonstrar que a sua participação direta representou um importante elo de ligação comunitária no conflito agrário. Além disso, o artigo pretende contribuir para a construção de uma memória histórica sobre a imprensa paranaense e de suas relações com a própria história do Paraná.

Palavras-chave: Rádio. Mediação. Levante agrário. Paraná.

\begin{abstract}
In 1957, the southwest of Parana was in a violent period, with the dispute of lands among colonists, leaseholders, companies of lands and the government. The situation reached its climax in October of that year, when colonists and leaseholders organized themselves into an armed conflict known as Revolta dos Posseiros de 1957, which happened in many cities of the region. In Pato Branco, the unexpected of this conflict is the mediation done through Colmeia Radio Station. This mediation aroused the political leadership of Ivo Thomazoni, radio announcer and one of the conflict's leaders. In this article, using oral testimonies, some characteristics of Colmeia Radio Station are
\end{abstract}

1 O presente artigo faz parte da pesquisa que originou o livro Dizeres em confronto: a revolta dos Posseiros de 1957 na Imprensa Paranaense, da autora, publicado em 2008. Guarapuava, PR, Brasil. 
done. The objective is to show that the direct involvement of this radio station was an important way of linking community in this agrarian conflict. Besides, the article intends to contribute to a historical memory about the press of Paraná and its relation to the history of Paraná.

Keywords: Radio station. Mediation. Agrarian revolt. Paraná.

\section{INTRODUÇÃO}

A imprensa, na sociedade contemporânea, assume funções que ultrapassam o conceito de mera transmissora de acontecimentos. Sua influência vai, até mesmo, além do direcionamento interpretativo. A própria condição de existência de um acontecimento está atrelada à sua publicidade. $\mathrm{O}$ historiador Pierre Nora (1979) chega ao ponto de dizer que, para haver acontecimento, é necessário que ele seja reconhecido como tal pela imprensa e por meio dela, pois somente ela tem à sua disposição possibilidades infinitas de manipulação da realidade. Nelson Traquina (2002), teórico da Comunicação, tem uma opinião semelhante. Ele lembra que os assuntos não pautados pela mídia são condenados à inexistência social, pois a imprensa direciona o quê, como e quando comentar. A imprensa adquire, assim, um papel significativo na construção da narrativa histórica contemporânea, enquanto poder simbólico formador de discurso histórico, já que os meios de comunicação assumem o papel de intermediários para que o acontecimento marque agora a sua presença. "E mesmo com muito mais força na medida em que os media impõem imediatamente o vivido como história, e que o presente nos impõe em maior grau o vivido" (NORA, 1979, p. 183-184).

No sudoeste do Paraná, o rádio foi mais além. Único veículo de comunicação da região em 1957, em meio a uma sociedade em sua grande maioria analfabeta, o rádio desempenhava o papel de informador, mediador e conselheiro. A proposta desse artigo é apresentar a participação da Rádio Colmeia de Pato Branco na Revolta dos Posseiros de 1957, levante agrário ocorrido em vários municípios sudoestinos.

Em meados de 1950, a região sudoeste do Paraná vivia um intenso conflito de terras. Colonos, posseiros, companhias de terras e governos estadual e federal disputavam as áreas onde se localizavam as glebas Missões e Chopim. Houve vários embates entre colonos, posseiros e as companhias grileiras. Alguns resultaram até em mortes.

Foi nesse contexto de violência e luta pela terra que surgiu o primeiro veículo de comunicação do sudoeste do Paraná, a Rádio Colmeia de Pato Branco. Para a pequena comunidade de Villa Nova (que futuramente seria chamada de Pato Branco), a experiência foi marcante, em uma época em que o poder de penetração do rádio nos lares era muito grande. O incentivo ao consumo levava cada vez mais brasileiros a adquirirem o aparelho. $\mathrm{O}$ seu crescimento enquanto veículo de comunicação acontecia quantitativa e qualitativamente, pois a informação ganhava espaço nas programações, através do radiojornalismo. "O rádio dilata o alcance da informação e dá à palavra a potência que lhe faltava, ampliando, por outro lado, as responsabilidades do jornalismo". (BAHIA, 1990, p. 169)

A Rádio Colmeia de Pato Branco representou o elo de ligação entre colonos, posseiros e lideranças do movimento pela posse de terra. A emissora fazia parte do dia-a-dia dos colonos e seus radialistas e acionistas tornaram-se, por isso, lideranças do movimento. A emissora estava presente em dois municípios da região: Pato Branco e Francisco Beltrão. Em cada um deles, mediou de forma diferenciada o conflito, pois pertencia a proprietários diferentes em cada cidade. Os dois veículos de comunicação não apenas forneciam informações ao público ouvinte, mas também alimentavam a imprensa da capital, pois somente no mês de outubro de 1957 alguns impressos enviaram repórteres para cobrir in loco o levante.

Nesse artigo, a partir de depoimentos orais de pessoas envolvidas no conflito, a mediação da Rádio Colmeia de Pato Branco a favor dos colonos será apresentada, principalmente na voz de um de seus radialistas, Ivo Thomazoni, que utilizou o rádio como megafone de luta.

O rádio mexia com a imaginação dos ouvintes. Principalmente nos meios rurais, era o único elo de ligação com o mundo exterior. Essa era a situação 
de parte dos moradores do sudoeste do Paraná, em sua grande maioria pequenos agricultores, vindos, sobretudo, de Santa Catarina ou do Rio Grande do Sul e analfabetos.

Infelizmente, as limitações técnicas da emissora não permitiram que se conservassem arquivos sonoros da programação em seu início. Assim, neste artigo, busca-se delinear algumas características da Rádio Colmeia de Pato Branco em seus primeiros tempos de atividade através dos depoimentos de alguns dos funcionários do período e da contextualização do momento histórico correspondente ao seu surgimento. As entrevistas foram feitas com Ivo Thomazoni, locutor da emissora na década de 1950, e Inelci Matiello, sonoplasta e, posteriormente, radialista esportivo.

Mesmo que os relatos, obtidos através da metodologia da História Oral (THOMPSON, 1992), sejam baseados em memórias individuais, eles são, por natureza, sociais também, pois os entrevistados estão inseridos em um grupo que compartilha experiências comuns. Além disso, falam de assuntos, situações que, se não tivessem significação na memória coletiva, não seriam compreensíveis. A memória individual é, também, resultado de um processo coletivo (MOTTA, 1998).

Através desse delineamento das características da Rádio Colmeia de Pato Branco, pretende-se contribuir para a construção de uma memória histórica sobre a imprensa paranaense e de suas relações com a própria História do Paraná. Assim, objetiva-se apontar algumas nuances das complexas relações que surgem entre o Jornalismo e a História, duas áreas tão vinculadas entre si na elaboração do discurso histórico na contemporaneidade.

\section{O INÍCIO DA RÁDIO COLMEIA DE PATO BRANCO}

Para pôr no ar a Rádio Colmeia de Pato Branco, os irmãos gaúchos Paulo e Otávio Rotilli, além de Norberto Bonher e Venignus Elisius Winkelmann, formaram uma sociedade para administrar a concessão da emissora. A Rádio Colmeia de Pato Branco passou a funcionar em caráter experimental em 31 de maio de 1954 e foi inaugurada oficialmente em 31 de julho do mesmo ano, na frequência $1.520 \mathrm{KHz}$ com potência de 100 watts. Rotilli assumiu a diretoria administrativa e a técnica ficou com Francisco Norberto Bonher (MIOT'TO, 2004).

Otávio Rotilli já tinha experiência na administração de rádios, pois dirigia a Três Passos, no Rio Grande do Sul. Foi ele quem viajou ao Rio de Janeiro, disposto a conseguir de Getúlio Vargas, com quem pretendia falar pessoalmente, uma concessão para uma emissora em Pato Branco. Após várias tentativas, conseguiu permissão para instalar três: uma em Pato Branco, uma em Toledo e outra em Francisco Beltrão, todas no Paraná. Posteriormente, foram autorizadas outras para várias cidades, como Campo Mourão, União da Vitória e Cascavel, resultando na Rede Colmeia de Rádios (MIOTTO, 2004).

Ivo Thomazoni chegou à emissora no mesmo ano. Ele conta que o convite para trabalhar como radialista se deu de forma inusitada. $\mathrm{Na}$ época, Thomazoni era responsável pelas compras de atacado de uma casa de comércio de Francisco Beltrão (município localizado a cerca de 80 quilômetros de Pato Branco), além de suas quatro filiais. Numa das viagens de União da Vitória a Pato Branco, em uma noite de clima ruim e estradas em péssimas condições, ele e o motorista da empresa tiveram que pernoitar em Pato Branco.

\section{Estavam instalando a rádio ao mesmo tempo em que anunciavam que estavam dando oportunidade para que os interessados fizessem testes de locutor. Eu ouvi durante o jantar. No dia seguinte, de manhã, continuou chovendo, e ounico meio de comunicação, de distração lá, era ouvir rádio. E se fazia esporadicamente, quando os motores davam a oportunidade de iluminar a cidade e dar luz e força (THOMAZONI, 2006, entrevista concedida à autora). ${ }^{2}$}

Thomazoni conta que seu colega de viagem, o motorista Santo Rosseto, o incentivou a fazer o teste. A justificativa era de que, em Francisco Beltrão, quem comandava os bailes através dos microfones era Thomazoni. $O$ teste consistiu na leitura de textos, no estúdio. O fragmento serve para mostrar como os primeiros profissionais da emissora

\footnotetext{
2 Neste artigo, preferiu-se por transcrever as citações dos depoentes tais como faladas.
} 
eram contratados, principalmente pelo potencial de sua voz e de sua comunicabilidade.

Vi um senhor, já bem mais velho do que eu, que depois de 10 ou 15 minutos em que en estava fazendo o teste, subiu e ficou na sonoplastia, me observando. Quando deu um intervalo, e uma música estava sendo rodada, ele chamou o rapaz que estava fazendo o programa e disse: deixa que esse moço faça sozinho o programa. Eu tremi, é verdade, mas fiz. o programa e acho que, meia hora depois, ele me chamou, fez sinal numa hora da música para que eu fosse conversar com ele. E me perguntou se en poderia comesar a trabalhar no dia seguinte. Eu disse: não, eu tenho interesses em Francisco Beltrão, então não será tão fácil me livrar de tudo que tenho lá (THOMAZONI, 2006, entrevista concedida à autora).

Foi assim que o catarinense, natural de Joaçaba, e que há dois anos residia em Francisco Beltrão, largou o trabalho na casa de comércio e mudou-se com família para Pato Branco. Além da facilidade comunicativa, o salário oferecido (segundo Thomazoni, o dobro do que ganhava no emprego que tinha então) ajudou na decisão.

Como todo começo de uma profissão, Thomazoni conta que não fácil. O início da era do rádio no Brasil exigiu de seus profissionais muita versatilidade. As poucas condições tecnológicas demandavam criatividade e esforço.

Primeiro comecei com a locução, mas tinha que fazer a redação também. Depois me puseram como responsável pelo departamento informativo. Eu tinha que fazer os jornais falados. Como na época os jornais lá chegavam com muito atraso, nós não podiamos fazer o que se chama, na linguagem de radialista, de os 'jornais gilete'. O 'jornal gilete' é aquele que você recorta o jornal e vai fixando num papel e depois lê. Então, tínhamos gravadores de fita, aqueles grandes, profissionais, eu ouvia, gravava o Repórter Esso, da Rádio Farroupilha e da Rádio Nacional. Eu gravava o Repórter Esso às $12 \mathrm{~h}$ e às $12 \mathrm{~h} 35$ eu já entrava com o noticiário. Então, eu tinha que ouvir a noticia e quase que imediatamente a divulgava. Eu não estudei estenografia, nem nada, mas aprendi a ser ligeiro em escrever, muitas vezes só eu entendia, mas pela metade. Inelci Mattielo era um garoto que eu tinha levado para lá, eu ouvia e à medida que escrevia, derrubava as folhas, ele ia juntando e organizando para depois me dar o que eu havia escrito para que eu pudesse dar a noticia fresca (THOMAZONI, 2006, entrevista concedida à autora).

Thomazoni trabalhou na redação e na locução, tornando-se, em pouco tempo, responsável pelo departamento informativo. É dele a primeira reportagem externa da emissora, na inauguração da Igreja dos Ucraínos. Cobertura de eleições, jogos de futebol, corridas de cavalos, além da transmissão de rituais católicos também fazem parte de sua experiência como locutor da Rádio Colmeia de Pato Branco. Como se pode perceber, o repertório de programas da emissora era variado.

Os programas que nós tínhamos à noite eram mais voltados para a cidade, com música relaxante, até "música de casaca", música clássica, nós púnhamos à noite sempre, alguns programas de tangos, boleros e poesias chamados lá de programas românticos. Os ouvintes da cidade se extasiavamporque os motores ${ }^{3}$ ficavam ligados até as 11 horas da noite, na hora em que nós também desligávamos o nosso motor pra descansar e fechávamos a rádio. Abríamos de manhã, 6 horas da manhã, com programa, ai sim, voltado para o interior, com música sertaneja, mais alegre, com recados e notícias. Era uma programação bem diversificada para que pudesse alcancar todas as camadas (THOMAZONI, 2006, entrevista concedida à autora).

Thomazoni comenta que, à noite, dificilmente a comunidade do interior do município conseguia sintonizar a faixa da Rádio Colmeia, pois havia muita interferência de emissoras argentinas. Mesmo com uma baixa potência (os 100 watts iniciais subiram para 250 watts somente em 12 de novembro de 1955), conseguia abranger toda a região.

A exclusividade da emissora de Pato Branco proporcionava aos seus locutores uma fama digna de artistas. É o que lembra Inelci Matiello, sonoplasta que iniciou carreira profissional aos 14 anos de idade, trabalhando junto com Thomazoni.

\footnotetext{
3 O fornecimento de energia elétrica, naquela época, dependia de uma locomotiva a vapor, o locomóvel, que funcionava até aproximadamente as 23 horas.
} 
Posteriormente, ele assumiu as funções de radialista esportivo e comentarista televisivo. Natural de Sarandi, Rio Grande do Sul, chegou a Pato Branco com sua família na mesma época em que começou a trabalhar na Rádio Colmeia.

Era 'Deus no céu e rádio na terra'. Uma cidade pequena, um sertão, digamos assim, com uma rádio. Os locutores eram tidos assim como verdadeiros astros [...]. Eram personalidades até, eu diria assim, personalidades. Porque não tinha televisão, não tinha telefone, não tinha internet, não tinha jornal... O rádio era uma coisa extraordinária (MATIELLO, 2006, entrevista concedida à autora).

A fama dos locutores ultrapassava os limites de Pato Branco. Em todo o sudoeste, os moradores acompanhavam a programação. Os avisos a parentes que moravam em cidades vizinhas eram dados através dos microfones da Colmeia.

Aspessoas entravam no estúdio e davam o recado. Aqui é a Fulana de Tal, o Fulano de Tal, quero avisar meu pai, não sei aonde, meu irmão, Fulano, venha a Pato Branco amanhã, ou estarei ai amanhã, me encontre na encruzilhada. O próprio povo ia para o microfone, se identificava e dava o aviso. Sem cobrar nada, veja a importancia! (MATIELLO, 2006, entrevista concedida à autora).

Para Eduardo Meditsch (2006), o surgimento do rádio foi a manifestação mais precoce da era eletrônica na comunicação de massa. A linguagem popularizou-se mais, buscando uma identificação maior com o seu público, em parte analfabeta ainda. Fortaleceram-se o radiojornalismo e a prestação de serviços (ORTRIWANO, 1985), duas áreas relevantes na Colmeia em Pato Branco. Como ainda não era possível falar em profissionais especializados no radiojornalismo e, ao mesmo tempo, a emissora tinha uma abrangência regional, a rádio buscou uma alternativa peculiar, revelada por Matiello (2006). "Na região, nós tínhamos correspondentes. [...] E as notícias daqui nós mesmos procurávamos por aî". Os correspondentes, quando achavam algum fato interessante de ser noticiado, enviavam a história por correspondência para a emissora, que relatava para os ouvintes.

É interessante observar que os próprios ouvintes tornavam-se repórteres e editores das informações que, posteriormente, fariam parte do conteúdo jornalístico da programação. Repórteres porque esses correspondentes iam atrás dos fatos, procurando por pessoas que pudessem dar informação. Editores porque funcionavam como filtros das notícias que achavam mais interessantes ao público, da qual faziam parte também. Era um trabalho voluntário feito por correspondentes que gozavam de credibilidade por parte dos locutores, garante Matiello.

Nós colocamos um aviso no ar, quem se interessava em ser correspondente. Muitas pessoas vinham para cá e não tinham ordenado nenbum, faziam isso por amor... Quer dizer, o rádio até hoje é forte, era mais forte ainda, não tínhamos televisão, então fariam esse trabalho por amor, gratuitamente para a rádio. Essas pessoas, tínhamos em Beltrão, Vitorino, Clevelândia, Mariópolis... Mas funcionava direitinho [...], não tinha outro recurso, absolutamente, não tinha telefone, não tinha nada (MATIELLO, 2006, entrevista concedida à autora).

Vale ressaltar que, na década de 1950, ainda não existiam periódicos impressos produzidos na região. Os jornais da capital demoravam muito para chegar a Pato Branco, pois ainda não existia asfalto nas estradas que ligavam o sudoeste à capital. Assim, praticamente não havia interatividade entre a imprensa do interior e a da capital.

Os jornais não divulgavam, Pato Branco era uma cidade pequena, pouca gente conhecia, onde é que fica isso e tal... Então nós realmente, posso garantir, não tínhamos comunicação na época. Tínhamos um jornal, o unico jornal, que vinha com atraso, vinha pelo onibus [...], saía de Curitiba pela manhã, chegava de noite em União da Vitória, chegava à noite do outro dia em Pato Branco. Então a única comunicação era realmente isso. Absolutamente não havia aquele laço de comunicação nos meios de comunicação, digamos, em rádio, Pato Branco e Curitiba (MATIELLO, 2006, entrevista concedida à autora).

A exclusividade regional da Colmeia de Pato Branco acabou no início de 1957, quando surgiu a Rádio Colmeia em Francisco Beltrão. As duas emissoras tiveram um papel fundamental no conflito de terras que amedrontava a região e eclodiu com a Revolta dos Posseiros de 1957. Especificamente 
neste artigo, apresenta-se apenas a participação da Colmeia pato-branquense.

Em 1957, a Rádio Colmeia de Pato Branco vivenciou duas experiências marcantes. A primeira foi a venda da emissora aos frades franciscanos. Esses, que há algum tempo manifestavam interesse em comprar a emissora de Otávio Rotilli, finalmente conseguiram adquiri-la. Matiello revela que Rotilli, assim como Thomazoni e outros envolvidos com os conflitos de terras que permeavam a região, corriam risco de vida, sendo constantemente ameaçados. Então Rotilli achou por bem vender a emissora de Pato Branco e de outras cidades também (MATIELLO, 2006).

A Província Franciscana adquiriu oficialmente a Rádio Colmeia de Pato Branco por 1 milhão e 800 mil cruzeiros. Nessa venda, houve a mudança do nome de Rádio Colmeia para Rádio Celinauta, cujo significado é "aquela que conduz ao Céu" (Coeli = céu e Nauta = navegante), como desejavam seus novos proprietários (MIOTTO, 2004).

A segunda experiência marcante para a história da rádio foi o envolvimento direto da Colmeia na Revolta dos Posseiros de 1957, discutido a seguir.

\section{A RÁDIO COLMEIA DE PATO BRANCO COMO PORTA-VOZ DE UM CONFLITO}

Pequenos agricultores, conquistados pela política de colonização do governo Moysés Lupion na década de 1950, buscavam no sudoeste do Paraná o sonho da posse de terra. Eles eram parte direta de um conflito pela legalização das áreas que possuíam. Pode-se dizer que o levante agrário de 1957 foi o ápice da disputa pela posse de terras das Glebas Missões e Chopim, as quais ocupavam quase a totalidade da referida região. A mesma área, ainda que em disputa entre os governos federal e estadual há vários anos, foi cedida a colonos através da Colônia Agrícola General Osório (Cango) e negociada como pagamento à companhia de terras Clevelândia Industrial e Territorial Ltda. (Citla). Essa transação foi contestada legalmente, graças às inúmeras irregularidades da operação. Além desses pretensos proprietários, ainda havia inúmeros posseiros na região (GOMES, 1987).

A situação complicou-se com a chegada das companhias de terras ao sudoeste-Citla, Companhia Comercial e Agrícola Paraná Ltda. e Imobiliária
Apucarana Ltda., sendo as duas últimas juridicamente desmembradas da primeira. As companhias imobiliárias eram classificadas de grileiras, por causa das irregularidades dos títulos de propriedade que emitiam, já que o seu direito de posse foi negado pela Justiça e, mesmo assim, vendiam terras sem autorização legal, mediante falsas escrituras de propriedade.

Os posseiros eram alvo tanto das companhias grileiras quanto daqueles que reclamavam a titulação das terras (GOMES, 1987). As companhias instauraram um regime de violência na região, com a contratação de jagunços, homens de índole duvidosa contratados para a manutenção da ordem imposta pelas companhias (BARROS, 2005, p. 267). Muitos habitantes foram expulsos ou fugiram para a Argentina, em sua área fronteiriça com o sudoeste paranaense.

Em 1957, colonos e posseiros organizaram diversas estratégias de resistência e luta às investidas de jagunços contratados pelas companhias grileiras para amedrontá-los e expulsá-los de suas terras. As ações dos jagunços eram violentas e resultavam em estupros, espancamentos, incêndios, depredações e até mesmo mortes. Em outubro daquele ano, colonos e posseiros se organizaram em um conflito armado, tomaram as suas cidades e expulsaram as companhias de terras e os jagunços, além de exigir a designação de novas autoridades municipais. $\mathrm{O}$ levante ocorreu principalmente nos municípios de Pato Branco, Francisco Beltrão, Capanema e Santo Antonio do Sudoeste. As emissoras Colmeia, tanto em Pato Branco como em Francisco Beltrão, participaram ativamente das estratégias de resistência, atuando como instrumentos de mobilização popular (PEGORARO, 2008).

John Thompson (2001) afirma que a possibilidade de um meio de comunicação levar as pessoas a experimentarem acontecimentos que se desenrolam em locais diferentes dos seus, em termos temporais e espaciais, pode criar e estimular formas de ação coletivas e organizadas. Ele explica que, quando as pessoas ligam os seus aparelhos, podem testemunhar fatos de importância histórica, em lugares próximos ou não. Dessa forma, as pessoas têm a oportunidade de partilhar experiências, independente das relações espaciais e temporais.

Pode-se dizer que a Rádio Colmeia foi o elo que possibilitou a mobilização coletiva de um povo, unido pela vontade de acabar com as disputas de terra e a violência que rondava o sudoeste 
do Paraná. Mesmo pessoas que, diretamente, não estavam envolvidas na luta pela posse de terra, como comerciantes e os moradores das cidades, acabaram por se sensibilizar pela causa dos colonos e posseiros, mediados pela ação direta das emissoras de rádio, tanto em Pato Branco como em Francisco Beltrão. O alcance regional da emissora, assim como o contato direto entre os seus funcionários, colonos e posseiros, propiciaram a participação direta da rádio no levante armado conhecido como Revolta dos Posseiros de 1957.

A voz do radialista Thomazoni era conhecida por todos aqueles que ouviam os programas da emissora. Entretanto, foi com olevante de 1957 que o seu nome passou a ser mais respeitado pelos colonos que procuravam a rádio em busca de ajuda - e odiado pelos políticos aliados de Lupion, já que Thomazoni tornou-se seu inimigo, falando abertamente contra ele através de seu programa ironicamente chamado Não atacamos, comentamos. De acordo com o locutor, o motivo principal dos ataques era o fato de Lupion e outros pessedistas da região estarem ligados a Citla, uma das companhias que promoviam a discórdia no sudoeste.

\begin{abstract}
Eu lembro bem que o Thomazoni conversou com o dono da rádio, o Rotilli, que não queria que a rádio entrasse na revolta, mas o apelo popular... eu me lembro de uma senhora que perdeu o marido e quatro filhos... isso eu me lembro bem. Chegou na rádio falando com o Thomazoni, pedindo pelo amor de Deus, justiça! Então a rádio se encaminhou pra esse lado, perigosamente se encaminhou pra esse lado... (MATIELLO, 2006, entrevista concedida à autora).
\end{abstract}

A participação da emissora acontecia de duas formas. A primeira com as intervenções do próprio Thomazoni, que emitia suas opiniões e denunciava os crimes. A segunda, quando os próprios colonos e posseiros iam até a rádio e desabafavam as injustiças que sofriam ao Thomazoni. Entre os depoentes, não houve consenso quanto ao uso direto ou não do microfone por colonos e posseiros (PEGORARO, 2008). Entretanto, ainda que eles não tenham falado diretamente no microfone, os relatos (mesmo mediados pelo radialista) serviam para aproximar os ouvintes, propiciando um efeito de realidade e uma gama de sentimentos, como revolta, indignação, solidariedade, simpatia do público pela causa dos colonos e posseiros. "A função mediadora que o jornalismo assume-entre os diversos discursos produzidos na sociedade e o seu público - faz com que processe e absorva em seu conteúdo os atos de fala de diferentes atores sociais" (MEDITSCH, 2006). Thompson complementa essa ideia, ao afirmar que

o processo de recepção não tem sentido único, mas é antes um encontro criativo entre uma complexa e estruturada forma simbólica, de um lado, e indivíduos que pertencem a grupos particulares eque trazem seus próprios recursos e pressuposições para os apoiar na atividade de interpretação, de outro lado (THOMPSON, 2001, p. 135).

A interação do contexto do receptor da informação com o dos personagens retratados pela mídia dá sentido ativo às mensagens, dotando-os de atitudes as mais diversas com relação às informações que apreenderam.

De um lado, a mediação através do rádio representou a solidariedade para com a causa de colonos e posseiros. De outro, representou uma alternativa para tornar públicas situações constrangedoras que não tinham a atenção devida das autoridades (GOMES, 1987).

Os posseiros sabiam da abrangência e da força que o veículo possuía na região. Além disso, confiavam nos radialistas que tanto admiravam. Esses assumiam, aos olhos dos posseiros, a representação de heróis, de justiceiros capazes de ajudá-los numa luta na qual o Estado parecia não estar do seu lado.

Então, os colonos passaram a confiar neste veículo de comunicação e no locutor que representava os colonos. [...] Contavam, choravam o que eles passavam. A maioria que perderam filho, perderam filha, perderam mulher, ou filho chorando a morte do pai, porque a comunicação era tão estreita... [...] quando o Thomazoni começou a fazer o comentário dele "Não atacamos, comentamos", os colonos vinham a Pato Branco, e eram entrevistados pelo Ivo, contando suas histórias, queperderam a terra, que incendiaram a casa, que mataram o gado, que mataram filhos e tal(MATIELLO, 2006, entrevista concedida à autora).

Thomazoni comenta que a possibilidade de falar sobre o problema que enfrentavam era mais que um desabafo para os colonos, era uma maneira 
de tentar enganar os jagunços das companhias. Ao mesmo tempo, acredita que a sua posição como locutor era um ponto positivo para os colonos, pois representava ameaça aos jagunços a possibilidade de irem ao ar os problemas da região.

Não raras vežes eles iam lá e diziam: "por favor, avisa a minha família que en estou viajando, que en viajei e só volto na semana que vem... Mas vocês cuidem de mim aqui, porque se eu for lá agora eles vão estar lá me pressionando e vão querer me bater. E agora não estou preparado, quero que eles pensem que eu fui buscar o dinheiro lá ou fazer alguma coisa". Mas isto era toda semana, nós tínhamos desses pedidos. [...] Todas as queixas eles queriam que fossem ao ar. Eles se sentiam bem quando o nome deles era citado, porque achavam que amedrontavao pessoal da Citla (THOMAZONI, 2006, entrevista concedida à autora)

Durante todo o levante, a emissora relatava aos ouvintes o que estava acontecendo. A participação da emissora de Francisco Beltrão, ainda que com suas particularidades, também foi fundamental para colocar a população a par do que estava acontecendo. Através das ondas do rádio, colonos e posseiros foram conclamados a vir para o centro de Pato Branco e Francisco Beltrão para participarem do levante. Comércio e indústria foram fechados como forma de protesto às violências das companhias. A comunidade, em um consenso mais amplo, estava a favor da revolta (WACHOWICZ, 1985; COLNAGHI, 1984).

As autoridades municipais foram depostas, sob acusação de serem coniventes com as companhias grileiras. Um grupo de revoltosos foi escolhido para negociar com o governo do Estado e indicar a escolha de novas autoridades nos dois municípios. Além disso, os jagunços foram capturados e expulsos da cidade, sob escolta militar. Em Francisco Beltrão, ainda, os escritórios das companhias de terras foram depredados e toda a documentação foi jogada pelas ruas do centro da cidade, constituindo uma das imagens mais divulgadas sobre a revolta. O levante também aconteceu em outros municípios da região, como Capanema e Santo Antonio do
Sudoeste, mas com algumas características diferentes em cada um deles.

Após o conflito de outubro de 1957, não há registros de continuidade de violências, pois os jagunços e as companhias de terras foram expulsos. Já os títulos definitivos de propriedade demoraram mais alguns anos para serem expedidos, mas foram garantidos a partir de 1962, com a instauração do Grupo Executivo para as Terras do Sudoeste $(\text { Getsop })^{4}$.

O discurso jornalístico pode ser entendido como o poder simbólico de construir versões da realidade, interpretando, privilegiando e dando visibilidade a sujeitos e situações, procurando, com isso, a própria legitimação de seu discurso perante a sociedade, através de sua função mediadora. Entretanto, como explica Pierre Bourdieu, a palavra por si só não tem poder. Sua eficácia simbólica depende de seu porta-voz e da credibilidade de que ele dispõe no campo social.

O poder simbólico como poder de constituir o dado pela enunciação, de fazer ver e fazer crer, de confirmar ou de transformar a visão do mundo e, deste modo, a ação sobre o mundo, portanto, o mundo; poder quase mágico que permite obter o equivalente daquilo que é obtido pela força (física ou econômica), graças ao efeito específico de mobilização, só se exerce se for reconhecido, quer dizer, ignorado como arbitrário (BOURDIEU, 1989, p. 14).

Esses conceitos permitem compreender a participação da Rádio Colmeia de Pato Branco no conflito de 1957, pois o poder de discurso de seu locutor foi preponderante na mediação do conflito e na transformação desse conflito em notícia para todo o Brasil e até mesmo para outros países ${ }^{5}$. No caso específico de Ivo Thomazoni, a credibilidade de seu discurso foi garantida pela representatividade de sua atuação profissional e pela identificação desse com a causa de colonos e posseiros.

Em meados de 1958, Thomazoni foi demitido da emissora pato-branquense, por motivos políticos, de acordo com o seu relato. Ele conta que

\footnotetext{
4 Para mais informações sobre a Revolta dos Posseiros de 1957, algumas sugestões: MARTINS, 1986; WACHOWICZ, 1985; VOLTOLINI, 2003.

5 A revista Life, em sua versão espanhola, publicou uma matéria sobre o assunto.
} 
Frei Inocêncio, um dos novos dirigentes da rádio após a venda, chamou-o e confessou que sua demissão havia sido um pedido pessoal do governador Lupion ao bispo da região.

E eu sai imediatamente, sem problema nenbum, voltei para Francisco Beltrão, para a mesma Casa de Comércio. Meses depois, eles me chamaram, os padres me chamaram de volta, porque o faturamento tinha caido, muitos comerciantes revoltados tinham tirado a propaganda que faziam na rádio. Ai eu voltei pra Pato Branco (THOMAZONI, 2006, entrevista concedida à autora).

E é a partir dessa volta que Thomazoni envolve-se mais diretamente com a vida partidária. Ele e alguns companheiros voltaram à frente do diretório regional da UDN (União Democrática Nacional), que pouco tempo antes haviam estabelecido para fazer frente ao PSD (Partido Social Democrata) e PTB (Partido Trabalhista Brasileiro), os dois mais fortes da região.

O discurso udenista no sudoeste ganhou força em 1958, logo após a revolta. Thomazoni lança-se como candidato a deputado estadual pela UDN, fazendo forte campanha contra Lupion, utilizando como argumentos a posição do governo estadual frente aos acontecimentos no sudoeste no ano anterior. Mesmo assim, os votos que recebeu não foram suficientes para elegê-lo, ficando na posição de suplente.

Vim para cá [Curitiba] como deputado em 1959, porque eu tinha ficado numa primeira suplência. No licenciamento do deputado João Vargas de Oliveira en assumie fir aquiviolentos discursos contra o governo eem defesa da legalização da posse de terras. A Assembleia Legislativa tinha por norma gravar todas as sessões. Então, os discursos feitos por mim aqui eu mandava para Pato Branco, e eles punbam na rádio. Discursos violentos (THOMAZONI, 2006, entrevista concedida à autora).

A estratégia surtiu efeitos no sudoeste, projetando-o como um nome de peso para disputar a Prefeitura de Pato Branco, em oposição direta ao PTB, com Alberto Pozza, e ao PSD, com Osvaldo Caldart. A proximidade com os colonos também foi outro fator que potencializou o nome de Thomazoni.
Ele foi o primeiro prefeito de Pato Branco que chegou até o fim do mandato; os dois anteriores renunciaram antes. Posteriormente, elegeu-se novamente deputado estadual em 1966, 1970, 1974 e 1978. Não chegou até o fim do último mandato em função de um enfarte, que o afastou da vida política. O trabalho como radialista não foi mais retomado.

\section{CONSIDERAÇÕES FINAIS}

O jornalismo participativo e mediado pelo microfone da emissora Colmeia fortaleceu a liderança política de Thomazoni, não apenas durante a revolta, mas posteriormente aos acontecimentos de outubro de 1957, até a solução definitiva pela legalização de terras.

Como já foi dito, a língua é um suporte de poder e quem a domina, quem tem condições de produzir o discurso, detém o poder não apenas sobre a língua, mas também sobre o seu capital. A palavra por si só não tem poder. Sua eficácia simbólica depende de seu porta-voz e da credibilidade de que esse dispõe no campo social.

No caso da Rádio Colmeia, os seus locutores, ou porta-vozes do conflito, dispunham de credibilidade suficiente para serem ouvidos e influenciar; consequentemente, detinham poder. Constata-se, assim, a presença de um discurso detentor de poder de legitimação, através de sua função mediadora. Portanto, a coerção aconteceu de forma indireta, sob o efeito da detenção do poder simbólico, que foi exercido a partir do discurso radiofônico. Uma luta simbólica que impôs uma definição de mundo social que mais se adequou aos interesses (individuais e coletivos) daqueles que representavam a rádio.

Nessa época, havia uma grande distância não apenas geográfica - entre a imprensa da capital e o público do sudoeste. A rádio estava presente na região, fazia parte do dia a dia dos colonos e posseiros (na maioria, analfabetos, portanto, sem acesso a periódicos impressos) e seus radialistas tornaram-se, por isso, lideranças do movimento. A impressa escrita acompanhava da capital, produzida e direcionada para o público da capital. A identificação por parte das emissoras regionais com a causa surgiu pelo reconhecimento de que havia ligações de pertencimento com o povo local. Por mais que os envolvidos fossem oriundos de diversas regiões 
do sul do Brasil, havia um interesse primordial entre todos: a luta pela legalização das terras.

Como explica Thompson (2001), o contexto de recepção das mensagens veiculadas pela imprensa é tão importante quanto o de produção. A apropriação dessas informações é um processo complexo, permeado pelas mais diversas disputas de interesse, que potencializam ações. No caso dolevante de 1957, representou a publicização da violência que assolava a região e incentivou a solidariedade por parte da sociedade urbana para com a causa de colonos e posseiros.

Após esses acontecimentos, em mãos dos frades franciscanos, a Colmeia de Pato Branco viveu dias pacíficos, já como Rádio Celinauta. A participação direta da emissora no levante mostra a importância que o veículo de comunicação desempenhou como elo comunitário nesse conflito. A identificação e a confiança dos ouvintes na emissora e nos seus radialistas reiteram, mais uma vez, que ainda é possível fazer um jornalismo participativo. Prova que o rádio pode servir, sim, como mediador e porta-voz dos grupos menos favorecidos, dando voz e vez a essas pessoas e auxiliando na resolução de problemas sociais. Além disso, reiteram que a imprensa, na contemporaneidade, assume um papel significativo na construção da narrativa histórica contemporânea.

\section{REFERÊNCIAS}

BAHIA, J.Jornal: história e técnica. São Paulo: Ática, 1990.

BARROS, L. Jagunço. In: MOT'TA, M. (Org.). Dicionário da Terra. Rio de Janeiro: Civilização Brasileira, 2005, p. 267.

BOURDIEU, P. O poder simbólico. Lisboa: Difel, 1989.

COLNAGHI, M. C. Colonos e poder: a luta pela terra no sudoeste do Paraná. 1984. 187 f. Dissertação (Mestrado em História do Brasil) - Universidade Federal do Paraná, Curitiba, 1984.

GOMES, I. Z. A revolta dos posseiros 1957. Curitiba: Criar Edições, 1987.

MATIELLO, I. P. Inelci Pedro Matiello: inédito. Pato Branco, 07 julho de 2006. Entrevista gravada concedida a Éverly Pegoraro, como parte integrante de sua pesquisa para a elaboração da dissertação de Mestrado em História Social. Dizeres em confronto: a revolta dos posseiros de 1957 na imprensa paranaense. (Os arquivos sonoros estão em posse da autora).
MEDITSCH, E. A nova era do rádio: o discurso do radiojornalismo enquanto produto intelectual eletrônico. Disponível em: <http://www.jornalismo.ufsc.br/ bancodedados/meditsch-novaera.html>. Acesso em: 30 jul. 2006.

MIOTTO, C. V. Rádio Celinauta $\mathbf{5 0}$ anos: ondas que unem o sudoeste do Paraná. Pato Branco: Fadep, 2004.

MOTTA, M. História e memórias. In: MATTOS, M. B. (Org.). História: pensar e fazer. Niterói: Laboratório Dimensões da História, 1998. p. 7-21.

NORA, P. O retorno do fato. In: NORA, P.; LE GOFF, J. História: novos problemas. 2. ed. Rio de Janeiro: Francisco Alves, 1979. p. 179-193.

ORTRIWANO, G. A informação no rádio. São Paulo: Summus, 1985.

PEGORARO, E. Dizeres em confronto: a revolta dos posseiros de 1957 na imprensa paranaense. Guarapuava: Ed. Unicentro, 2008.

THOMPSON, J. A mídia e a modernidade: uma teoria social da mídia. Petrópolis: Vozes, 2001.

THOMAZONI, I. Ivo Thomazoni: inédito. Curitiba, 12 set. 2006. Entrevista gravada concedida a Éverly Pegoraro, como parte integrante de sua pesquisa para a elaboração da dissertação de Mestrado em História Social. Dizeres em Confronto: a Revolta dos Posseiros de 1957 na Imprensa Paranaense. (Os arquivos sonoros estão em posse da autora).

THOMPSON, P. A voz do passado: história oral. Rio de Janeiro: Paz e Terra, 1992.

TRAQUINA, N. O estudo do jornalismo no século XX. São Leopoldo: Ed. da Unisinos, 2002.

WACHOWICZ, R. C. Paraná, sudoeste: ocupação e colonização. Curitiba: Lítero-Técnica, 1985.

Recebido: 24/07/2009

Received: 07/24/2009

Aprovado: 05/10/2009

Approved: 10/05/2009

Revisado: 11/01/2009

Reviewed: 01/11/2009 